\title{
Analysis of Education-Themed Films in the Context of Teacher Education Programs
}

\author{
Suna Arslan (Corresponding author) \\ Cumhuriyet University, Faculty of Education EBB Sivas, Turkey \\ E-mail: suna_karakucuk@yahoo.com
}

Received: March 15, 2017

doi:10.5296/jet.v4i2.10916
Accepted: June 28, 2017

Published: August 11, 2017

URL: http://dx.doi.org/10.5296/jet.v4i2.10916

\begin{abstract}
The study aims to answer the question: "Is it possible to benefit from education-themed films in teacher training policy?" For this purpose, students of the Faculty of Education were placed in film viewing/interpreting groups and were asked to determine the meanings conveyed in the following films: "Hababam Sinıfi," "Sinav," "Elephant," and "Dead Poets Society." The findings obtained through content analysis were themed. Results showed that catchy/effective scenes and cues were grouped under the following main themes: Education, family, society, and adolescence. The most intensely-perceived main theme was the messages on the education system. The fact that education took first place and that this was followed by adolescence, society, and family-themed messages shows that the education phenomenon should be discussed with respect to these concepts.
\end{abstract}

Keywords: Movies, Educational films, Teacher training.

\section{Introduction}

The basis of this research is an approach that brings together the methods of education and art. These are two social establishments that have common grounds and benefit from the work of motion pictures, which is a branch of Fine Arts, allowing for meeting educational goals.

The most naive goal of the suggestion of "watching film in the class" is to carry the magical air of "the seventh art" to education. Through this, audiences transition from passive perception to active cognitive activity which is called "creation of effective impulse by the films" (Monaco, 2001: 371). It is thought that good knowledge of films and archives will include reinforces that support didactic education and bring natural environments/constructive communications to teacher-student relations.

Motion pictures are a phantom of art. In fact, it is the seventh art as it is the combination of painting, sculpture, music, theater, dance, literature, and architecture (Monaco, 2001). Motion pictures are a language with a unique dramatic structure, theme, code, and indicators (Özön, 1964). Bazin (1993) says that motion pictures add a new language to art through the richness 
of its expressional opportunities. Motion pictures, which have been defined as only a new invention and with its new technical features, has become a public education environment/device as it has become a part of social life and entertainment.

The beginning of motion pictures came with the advent of silent motion pictures in 1876 . Mitry (1989) says that motion pictures were born in the $19^{\text {th }}$ century, but belong to the $20^{\text {th }}$ century. It can be said that the existence of motion pictures as an educational device started when it was born. Can (2005:31) mentions that films with educational goals started in 1910 with Thomas Edison. Edison claimed that films have an infinite learning potential and that they would revolutionize the education system and take the place of books. In 1919, the visual education movement occurred in the USA, while in 1920 the "Educational film movement" occurred and educational films were archived. In 1960, Jerome Bruner suggested films and short films in the scope of education reform in his book Education Process.

At the present time, organizations that support education system state that films are a resource that include curriculum with the names: "films education, films in class" and they present literatures that support creation of cinema culture (http://www. filmeducation.org).

Motion pictures entered Turkey in 1896; the first film screening to public was in 1908 (Özön, 1964). The meeting of motion pictures with education occurred with the establishment of the Educational Films Center in 1951. The establishment of the Films, Radio and Television Education Center in 1968 shows that efforts to use educational films in formal and non-formal education continue. Motion pictures are gaining popularity, reinforcing their educational function as well as their role in entertainment. In today's world, creating a stimulus-rich environment and using educational or artistic films in educational environments and in the education of teachers is supported by learning objects such as short films, films, animations, and video films etc. (Yeşilyurt, 2010). Film centers or cinema clubs in universities are supported but it is difficult to say that there is benefit from films as an educational material in primary and secondary education. For an example of the few practices in this respect, please see: meb.gov.tr/okulda-sinema-keyfi.

National and international studies of the use of educational films and their benefits are generally recent. Michel et al. (2007) say that before educational films were used in course subjects, they were used as "advance organizers." There is some research suggesting that films should be used in teaching concepts about health education, psychology etc. (Barnett et al. 2006; Lawson et al., 2007; Rabow et al., 2010). Whiteman (2009) also thinks that films with educational purposes can be used in public education and in order to reach large masses of people. Bruner (2008) mentions the disadvantages of substitution of teachers by films and suggests films as devices that indirectly enrich education processes. Moreno and Mayer (1999) go one step further and defend the following view: "Films will be used instead of books in all of the schools in the next ten years." An experience that supports this thesis is Gilmour's (2010) book Film Club. The writer tells of the efforts of a father in order to educate his own son, who has decided to leave school, through film watching, and understanding and teaching programs. In Turkish literature, Tezcan (1972) thinks that motion pictures have the power to change behaviors in terms of public education. Other examples of 
recent studies include: The effect of films in history education (Öztaş, 2008) and social studies (Öztaş, 2009; Kaya and Çengelci, 2011); the use of motion pictures as a tool for socialization (Birkök, 2008); and films as the subject of education (Akbaş, 2011). Besides these advantages to educational films, their limits have also been discussed: Demircioğlu (2007) thinks that films have limits inasmuch as they make students passive, are inappropriate for students' levels, lead to incorrect interpretations, and create prejudice.

This research searches for answers to these questions for the aim of benefiting from films with a multi-disciplinary approach to teacher training programs. The following questions are asked:

1. What are the common messages/main themes perceived by teacher candidates in the films they watch?

2. Are the universal problems of education reflected in the Turkish films and foreign films used as samples for this research?

When the processes of searching for answers to these questions and evaluating the obtained results are completed, it is possible to study and discuss the phenomenon of watching films in teacher training programs. This contributes to the professional readiness of teacher candidates and observation of them in school environments.

\section{Method}

This study utilized content analysis, using the approach of "how a film affects" audiences (i.e., its function). This question is more significant than the question "what is the film" that is being analyzed (i.e., its form) (Monaco, 2001). Bilgin states: "Content analysis is a 'second reading' whose goal is to determine the factors in a message that affects individuals without being seen. In this respect, content analysis is reminiscent of the art of perceiving what is conveyed" (2006). In choosing film samples of the study, the standards of "good film" (time-space accordance, intellectual intensity of dialogs, originality, acting etc.) in the studies of Can (2005) and Adanır (2003) were taken into account. In the standard of "education-themed films" the research of Karaküçük (2011) and Güven (2008), filmographies and film criticisms were used. At the end of document analysis, four films were chosen for analysis: "Hababam Sınıf,," "Sınav" (Exam), "Ölü Ozanlar Derneği” (Dead Poets Society), and "Fil" (Elephant).

Qualitative Approach-Focus Group Discussions were appropriate for the goal and structure of the research. Cinema and semiology theories state that "there is main code (fiction) and sub-codes; codes show the basic meaning" (Metz, 2012) and that "what we read in films are only codes" (Monaco, 2001). The research model of this study was formed according to these approaches. Chosen films were shown to teacher candidates during the 2014 academic year and their views about the perceived contents and effective messages were sought. Content analyses of recorded interviews were made and obtained findings shown in tables.

Qualitative methods focus on describing events and facts in their natural environments, understanding and reflecting the views of participants, and following an intellectual approach 
with flexible, contextual and generalizable features. Document analysis, focus group discussion, and metaphor analysis techniques were used together in this research in accordance with the integrative feature of the qualitative approach (Kuş, 2003; Glesne, 2013). Interview questions were based on the determination that "motion pictures talk and move" (Monaco, 2001: 395) and were as follows: "What are the lines/speeches that affected you/remained in your mind?" and "What are the scenes that affected you/remained in your mind?" It was hypothesized that teacher candidate participants would enable the reaching of personal views and the obtaining of data that is pedagogically significant.

\section{Results}

Table 1. Main Themes and Themes of Hababam Sinıfi (Hababam Class, 1975) (Author: Rifat Ilgaz, Director:Ertem Eğilmez) Film According to Audience Perceptions*

\begin{tabular}{|c|c|c|c|}
\hline Messages about education system & Messages about family & Messages about society & Messages about puberty \\
\hline Education critique, negative 41 & Family critique 11 & Teacher Mahmut 59 & Teenager/student jokes 26 \\
\hline Education-İndiscipline 31 & Motherlike /Hafize Ana & Humane dimension 21 & Friendship, positive 22 \\
\hline Teacher model, positive 31 & 8 & İnek Şaban/Cow Şaban 18 & Teenager behavior,negative 15 \\
\hline Punishment 24 & Substituting for family & Film, positive critique 17 & Developmental disturbance 9 \\
\hline Education/School environms 22 & 4 & Damat Ferit/Groom Ferit 10 & Identification with Hababam Class \\
\hline Teacher model, negative 21 & Family model 2 & Hafize Ana /Hafize Mom 8 & 8 \\
\hline Teacher-student communication, positive & Mother model, negative & Identification with Teacher & Teenager solidarity 7 \\
\hline 19 & 2 & Mahmut 8 & Image of body 3 \\
\hline Education activity 15 & Father model, negative & Güdük Necmi/Stuby Necmi 7 & Teenager behavior, positive 3 \\
\hline Education critique, positive 8 & 1 & Domdom/Fat 4 & Teenager/student model 2 \\
\hline Creativity-ability 4 & & Coinciding with today 4 & Friendship, negative 1 \\
\hline Fitting today 3 & & Külyutmaz 3 & Student discourse 1 \\
\hline Teacher-student communication, negative & & Manager/Boss 3 & \\
\hline 3 & & Baby 3 & \\
\hline Exam 2 & & Social change 3 & \\
\hline \multirow[t]{2}{*}{ Teacher joke 1} & & Doorkeeper 2 & \\
\hline & & Rifat Ilgaz 2 & \\
\hline Education: 225 & Family: 28 & Society: 171 & Puberty: 97 \\
\hline & & & General Total: 521 \\
\hline
\end{tabular}

* Numbers next to the themes are code frequency numbers

As can be seen in Table 1, at the end of the qualitative interviews with teacher candidates, the most frequent messages in "Hababam Sinıfi" were determined to be messages about the education system" (225). This is followed by messages about society (171), messages about puberty (94), and messages about family (28). According to this, Hababam Sinifi is "a film of education and society." When the distribution of messages about education was analyzed, it was seen that the primary perception of audiences concerned the negative sides of education (41). Perceptions of disciplinary action (31), punishment (24), and negative teacher models (21) were frequently repeated and supported this finding. The positive teacher model in the third line (31) is reminiscent of the character of Teacher Mahmut, which support the positive 
teacher-student relation (19) finding. The "education/school environment" (22) in the fifth line can be explained via the fact that all of the events in the film occured in a boarding school and the originality of school buildings in the film (Adile Sultan Kasr1-pavilion). This is followed by "positive education criticism" (8) in the eighth line.

In the society theme, the character of Teacher Mahmut (59) was perceived in the first line as a character that is a social role model who provides lessons about real life. This feature of Teacher Mahmut is in accordance with the themes "humane dimension" (21) and "identification with Teacher Mahmut" (8). There is "İnek (cow) Şaban" (18) in the third line, which refers to a character that loves his friends and vice versa. The perception of "Positive criticism for the film" (17) is an example of a successful combination of the art of literature and motion pictures by the writer Rifat Ilgaz and director Ertem Eğilmez. There is laos the perception of "Damat (groom) Ferit" (10) in the sixth line, which is a reference to the interesting student character who is handsome and married with kids. The character "Hafize mom" (8) who reflects the feeling of motherhood in the school, features in the sixth line.

In the first line of messages in the film about puberty, the "student jokes" (26) are emphasized. As per the association with the word "Hababam" (Hababam; can be explained with the idiom of "blackboard jungle"), it is natural to have such an audience perception of the film. The phrase "positive friendship bonds" appeared in the second line. The fact that students are in a boarding school and friends substitute for family explains these first two results. Some of the friendship bonds were perceived as "negative teenager/student behavior" (15) and "developmental disturbance" (9) resulting from this in line four. The audience "identifying with Hababam class" (8) can make audiences think that the film is a work that represents student life and friendships that have been lived or that one seeks to live. The lower prevalence of messages about family and the perception of family criticism in the film can be explained with paid/boarding education and the indifference of families with reference to school.

Table 2. Main Themes and Themes of Dead Poets Society (1989), (Author: N. H. Kleinbaum, Director: P. Weir,) Film According to Audience Perceptions

\begin{tabular}{|c|c|c|c|}
\hline Messages about education system & Messages about family & Messages about society & Messages about puberty \\
\hline 1. Teacher models 23 & 1. Prevention of ability 9 & 1. Self-fulfillment 9 & 1. Friendship bonds 15 \\
\hline (positive:18 negative:5) & 2. Fitting today 7 & 2. Freedom/Free & 2. Love/liking 12 \\
\hline 2. Carpe Diem 22 & 3. Negative father model4 & thinking 8 & 3. Self knowledge 11 \\
\hline 3. Education criticism, & 4. Self destruction 4 & 3. Carpe diem 7 & 4. Fitting today 9 \\
\hline Tearing book 14 & 5. The young's not having the right of & 4. Fitting today 5 & 5. Ability/field of interest \\
\hline 4. Art education-Poem 11 & election 2 & 5. Change 5 & 9 \\
\hline 5. Different point/stepping on school & 6. Choice of profession 2 & 6. Social models 4 & 6. Interest in poem 9 \\
\hline desk 10 & 7. Intolerance 1 & 7. Red Indian /Nuanda & 7. Personality difference 8 \\
\hline 6. Fitting today 10 & 8. Loveless family 1 & 4 & 8. Private space/cave 7 \\
\hline 7. Teacher that is loved 10 & 9. Birthday-gift 1 & 8. Captain metaphor 4 & 9. Criticizing adults 6 \\
\hline 8. Positive school environment 9 & 10. Punishment 1 & 9. Life/Death 2 & 10. Sports 6 \\
\hline 9. School environment 7 & & 10. Realism 2 & 11. Self destruction 4 \\
\hline
\end{tabular}


11. Existentialism 2

12. New experiences 2

13. Radicalism 2

14. Meaning of life 2
12. Gaining confidence 3

13. Entertaining/Free time 2

14. Choice of profession 2 15. Carpe Diem 2 16. Puberty features 2 17. Necessity of counseling 2

15. Learning thinking 4

16. Punishment 3

17. Necessity of guidance 3

18. Shakespeare 2

Education: 158

Family: 32

Society: 58

Puberty: 110

General Total: 358

As can be seen in Table 2, the most frequently repeated messages of the film "Dead Poets Society" concerned the education system (158). This was followed by messages about puberty (110), messages about society (58), and messages about family (32). These results show that the film's theme is "education and puberty." Messages about society are similar to those with themes about puberty. It can be seen from the table that messages about family are the least frequently mentioned message and is inclusive of negative features.

The most readily-perceived lines and themes in the classification of the education main theme are about "Teacher models" (23). Mr. Keating presents a "Positive teacher model" (18) and is a significant alternative for a teacher type who defends a traditional system. The discourse of "Carpe diem" (22), the motto of the film, is perceived in the main themes of education, puberty and society. Although the film was made in 1989, it can be seen from the table that, the perceived message of "Fitting today" (10) shows that the film is timeless.

The second main theme in Dead Poets Society concerned messages about puberty and included positive feelings and demands. When sub-themes were analyzed, it was seen that there was a "friendship bond" (15) perception in the first line, in accordance with the fact that the characters are young people in boarding high school. Scenes and lines that are generally associated with puberty have universal features such as the search for private space, a sense of belonging, revolt, the search for identity, interests/abilities, love, self-destruction etc.

Contents of the film associated with social messages included: "self-fulfillment" (9), "freedom" (8), "carpe diem" (7), and "change" (5). There was a low frequency of the perception of family and this association, when present, was completely negative. This is understandable; the reasons can be seen in the themes including prevention of ability (9), negative father model (4), and Neil's self-destruction (4). In other words, the reality reflected in the film is that expectations of young people and teenagers do not easily fit into the role models for school and family. 
Table 3. Main themes and themes of the film "Elephant" (2003), (Gus Van Sante) According to Audience Perceptions

\begin{tabular}{|c|c|c|c|}
\hline Messages about education system & Messages about family & Messages about society & Messages about puberty \\
\hline 1. School environment 50 & 1. Loveless mother 12 & 1. Negative social & 1. Tendency to violence 18 \\
\hline (Positive 48 Negative 2) & 2. Home environment 7 & models/symbols 15 & 2. Friendship bonds 16 \\
\hline 2. Counseling/positive 25 & (Positive 4- Negative & 2. Exclusion 12 & (Positive 8- Negative \\
\hline 3. Teacher Models 14 & 3) & 3. Negative environment & 8) \\
\hline (Positive 4 Negative 10) & 3. Negative family model 6 & 12 & 3. Character difference 13 \\
\hline 4. Fitting today 11 & 4. Negative father model 4 & 4. Obsession for justice & 4. Self-Expression 10 \\
\hline 5. Exclusion/friendlessness 11 & 5. Fitting today 4 & 10 & 5. Hating fellows 9 \\
\hline 6. Ability 10 & 6. Computer-violence & 5. Expectation of social & 6. Intolerance 9 \\
\hline 7. Violence in school 6 & games 4 & approval 4 & 7. Understanding, tolerance 9 \\
\hline 8. Punishment 5 & 7. Metaphor of elephant 3 & 6. Hating society 3 & 8. Sexual problems 8 \\
\hline 9. Hating teachers 5 & & 7. Fitting today 2 & 9. Negative body image 8 \\
\hline \multirow[t]{9}{*}{ 10. Tolerance 1} & 8. Family pressure 2 & 8. Social norms 1 & 10. Puberty problems 4 \\
\hline & & 9. Punishment 1 & 11. Swearing/verbal violence \\
\hline & & & 3 \\
\hline & & & 12. Group conscience 3 \\
\hline & & & 13. Identity complex 2 \\
\hline & & & 14. Computer-violence \\
\hline & & & games 2 \\
\hline & & & 15. Friendlessness 1 \\
\hline & & & 16. Ability/interest 1 \\
\hline \multirow[t]{2}{*}{ Education: 138} & Family: 42 & Society: 60 & Puberty: 116 \\
\hline & & & General Total: 356 \\
\hline
\end{tabular}

At the end of the qualitative interviews with teacher candidates, it was determined that the majority of messages in the film "Elephant" film were about the education system (138). This prevalence was followed by messages about puberty (116), society (60), and family (28). According to audience perceptions, Elephant is "a film of education and puberty."

In the messages about the education system, it was the seen that school's physical and social conditions (48) were positively perceived. Other positive aspects included the audience perceiving opportunities about counseling (25) and ability (10). Teacher models (14) in the film were perceived mostly negatively (10). On the other hand, the totality of positive messages about the education system (90) in the film were greater than the totality of negative messages (48). For this reason, we think we should look for the real reasons for violence in school in other themes (family or society).

There were messages about puberty (116) in the second line and most of these were negative (76). This included tendencies to violence, negative friendship, hating fellows, sexual problems, negative body image, computer games that contain violence etc. Based on these 
findings, it can be said that, the film attracted audience attention to education processes during puberty.

Messages about society (60) in the film were also negative for the most part (53). According to audience perception, the young are raised in conditions featuring social models, exclusion, social hate, etc. The object that became prominent in the film was gun/arming and objects of crooked cross and demon figures. These are all social symbols signaling violence. The category of messages about family is the category perceived the least by audiences (42) and is mostly negative (31). These findings explain the family reasons for violence in school.

Table 4. Main Themes and Themes of the film "Sinav/Exam,"(2006) directed by Ömer F. Sorak according to Audience Perceptions

\begin{tabular}{|c|c|c|c|}
\hline Messages about education System & Messages about family & Messages about society & Messages about puberty \\
\hline 1. Exams 45 & 1. Mother-father model 37 & 1. Social rules 23 & 1. Character differences 12 \\
\hline 2. Counseling 29 & (positive 10- negative 27) & 2. Social models 9 & (positive 11 - negative \\
\hline 3. Teacher model 25 & 2. Family pressure 18 & 3. Fitting today 8 & 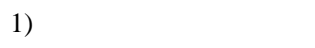 \\
\hline (positive 7-negative 18) & 3. Family love 7 & 4. Negative Social & 2. Positive friendship 5 \\
\hline 4. Fitting today 23 & 4. Youngs no have the & environment 6 & 3. Self-expression 5 \\
\hline 5. Race horse metaphor 14 & right of election 4 & 5. Expectation of social approval & 4. Group cooperation 4 \\
\hline 6. Dostoyevsky 6 & 5. Race horse metaphor 2 & 1 & 5. Fellow counseling 2 \\
\hline 7. Punishment 4 & 6. Uneducated parent 2 & & 6. Identity complex 2 \\
\hline 8. Youngs no have the right of & 7. Prevention of ability 2 & & \\
\hline election 3 & 8. Lack of mother-father 1 & & \\
\hline Education: 149 & Family: 73 & Society: 47 & $\begin{array}{l}\text { Puberty: } 30 \\
\text { General Total: } \mathbf{2 9 9}\end{array}$ \\
\hline
\end{tabular}

The most catching messages of the film "Sinav" (Exam) according to audience perceptions fell under the theme "Education system" (149). This was followed by family (73), society (47), and puberty (30) as other main themes. According to these findings, "Sinav" describes "education and family" problems as told through relationships, or by reflecting the messages in one another.

In the film, the exam system (45) is illustrated as the main problem of the education system in Turkey. This theme is followed by "Counseling" (29) and "Teacher models" (25). While most perceptions about teachers were negative (18), all of these are determinations that "fit today's world" (23). The metaphor of "race horse" (37) is repeated frequently, symbolizing the situation students face.

In the messages of the film about family (73), "parent model" (37) appears in the first line. The number of negative models (27) in this theme show that perception of family pressure (18) and hopelessness about the education system also exist in the family. The results of the 
young's having no right of election (4), uneducated parents (3), and prevention of ability (2) confirm this finding.

Messages about society in the film (47) are few. Social rules are perceived in the first line (23), while the social models (9) and social environment (6) themes are generally negative. The perception of fitting today (8) in the third line can be interpreted as the idea that the criticism still continues. In the messages about puberty (30), there are character differences (12) in the first line that are described completely positively (11). This reflects the sympathy/hope of the film about the young. Positive friendship bonds (5), self-fulfillment (5), and group cooperation (4) support this finding.

On the other hand, it can be seen in the table that the repetition of the themes "fitting today" (28) and "race horse" (16) emphasize the perceptions of the situation of students who are forced to compete in educational and family structures in Turkey.

\section{Discussion}

The results of this research show and support the idea that film samples from either good films or educationally-themed films can be used in teacher education programs. This is in accordance with the results of many other studies, including that of Tezcan (1972), Demircioğlu (2007), Pekdağ and Le Marechal (2007), Birkök (2008), Öztaş (2008), and Kaya and Çengelci (2011). Results of the study by Kaşkaya et al. (2011) have some similarities with the results of this study, which are as follows: Films can make significant positive contributions to teacher candidates' attitudes toward professions and self-reliability perceptions, and educational films can be used in teacher training programs. Sevim (2011) analyzed puberty problems in his research using "Dead Poets Society". Sevim placed educational institution in the second line of the film's content, which accords with the results of this research. Koçak (2007) is another researcher who used "Dead Poets Society" in terms of educational units. He states that the film's content (inclusive of the teacher, students, managers, school buildings and education programs) are appropriate for analysis. This statement is in accordance with the results of this research. There are evaluations in online film resources about "Dead Poets Society" in which it is mentioned that the film is inspiring with regards to education (enisden.wordpress.com), and the fiction is based on teaching success (okul.selyam.net). These results support the result of this study, namely that "Dead Poets Society" can be used in teacher training programs.

In this research, it was determined that "Elephant" is a film of education-puberty; this accords with interpretations of the film in national and international literature. In film blogs (Halflants, 2003) that is, interpretations of the film are similar, with experiences and deaths of young characters in the film analyzed through personalization. The theme of violence is discussed by combining the symbol of the elephant with different interpretations. This determination can be interpreted by combining it with the third main theme of the research, which is the social dimension. In the episodes of film, there are references to social systems (Hitler Nazism, individual armament in the USA, etc.) as resources for violence. No other pedagogical studies exist in the literature about the Turkish cinema sample "Hababam Sinıfi". "Hababam Sinıfi" is in all of education-themed and popular movie classifications (Asutay, 
2001; Cans1z 2011; Güven, 2008; et al.). The findings of this research show that the main themes of "Hababam Sinifi" focus on education-society. These are in accordance with the results of a small number of cinema and literature studies that make different analyses. For instance, Hidıroğlu (2011) emphasizes that the topics of the film are the faulty education system, the young who are raised without interest and the suggestion of "ideal education, with educators in each field of society/life." There are also no extant studies for the other Turkish film sample used in this research, "Sinav". It was determined in this research that, the themes of this film are education and family. That is, these are the first sample findings about the film. "Sinav" deserves analysis as it is a significant semi-documentary which makes significant criticisms about the education system through children who are used like they are "race horses."

\section{Conclusion}

The basic question of this research is "Can we benefit from filmic presentation of visual information/documents, entertaining or cathartic effects in education environments/teacher trainings?" Observational and qualitative study results show that watching and discussing good film/education-themed film samples are a useful method in teacher training. The results of the study with regard to audience perception/messages are as per the below:

1. Messages of the films "Hababam Sinıfi," "Dead Poets Society," "Elephant," and "Sinav," as per the perception of audiences/teacher candidates contain content that falls into the themes of "education," "society," "family," "puberty."

2. It was seen that the primary/common perceptions all four films had in common concerned the "education system." This result shows that these films contain many topics, experiences, problems, and information, which may be successfully transferred to audiences. Education appeared as the main theme in the first line for each of the four films. This shows that the sampling choice of films is appropriate for the standards of education-themed films. The success these films have in transferring these themes to audiences, shows that they are qualified pieces of art. Thematic aspects of the analyzed films are as per the below:

"Hababam Sinıfi" is an education-society film; issues of puberty and family are reflected or perceived relatively infrequently.

"Dead Poets Society" is an education-puberty film; issues about society and family are reflected or perceived less frequently.

"Elephant" is an education-puberty film; issues about society and family are reflected or perceived less frequently.

"Exam" is an education-family film; society and puberty problems are less frequently reflected or perceived.

3. There are perceptions about "fitting today" (86) as one of the thematic values of the films, which is very interesting. Although these films were made in different times $(1975,1989$, 2003, and 2006) the total repetition time of thematic perceptions in the four films about 
education, society, family, and puberty emphasize that this problem/situation still continues today.

4. The generalizable results of this research include the idea that issues about education should be discussed without being isolated from the concepts of society, family and puberty.

5. In this research, it was observed that the activities of watching and discussing education-themed films have a positive effect on the professional readiness of teacher candidates. It has been suggested that this effect should be evaluated in a future research study.

6. The most important outcome of this research is that we ought to design and place art education, creative activities, watching/analyzing film etc. in the education programs of candidate teachers in order to ensure that they become skilled in the reception and interpretation of art.

\section{References}

Akbas, O. (2011). Educational short films as learning objects: Assessment of educational short films made by prospective teachers. Gazi University Journal of Industrial Arts Education, 27, 15-27.

Adanir, O. (2003). Meaning and narration in cinema. Istanbul: Alfa Publications.

Asutay, H. (2001). Language of youth. Dokuz Eylul University Journal of Institute of Social Sciences, 3(2), 1-22.

Barnett, M., Wagner, H., Gatling, A., Anderson, J., Houle, M., \& Kafka, A. (2006). The impact of science fiction film on student understanding of science. Journal of Science Education and Technology., 15(2), 179-190.

Bazin, A. (1993). What is cinema? (Trans. I. Sener). Istanbul: Sistem Publications.

Bilgin, N. (2006). Content analysis-techniques and sample studies in social sciences. Ankara: Siyasal Bookstore.

Birkok, M. C. (2008). Using alternative media in education as a means to socialization: Motion pictures. Journal of International Humanities, 5(2), 1-10.

Bruner, J. (2008). The process of education. (Trans. Talip Ozturk). Ankara: Pegem Academy.

Can, A. (2005). Short film. Konya: Tablet Publishing House.

Cansiz, A. B. (2011). Adaptation of novels as literary work into cinema and television and the changing narrative language. [Online] Available: rtuk@rtuk.gov.tr(June 1, 2013).

Demircioglu, I. H. (2007). The place and importance of films in history education. Bilig, (42), 77-93.

Gilmour, D. (2010). The film club. (Trans. Dost Korpe). Istanbul: Domingo Publication.

Glesne, C. (2013). Becoming qualitative researchers: An introduction. (Trans. Ali Ersoy, 
Pelin Yalcinoglu). Ankara: Ani Publications.

Guven, A. M. (2008). Movies on school and education life in the history of cinema.Retrieved from http://www.ikinciperde.com/sinemayadair/makaleler/227 (June 1, 2013).

Halflants, L. (2003). Film analysis and criticism. [Online] Available: ObscuraCinéma (June 1, 2013).

Hidiroglu, I. (2011). An auteur in Yesilcam Cinema. Journal of Ataturk Communication, (1), 25-43.

Kaskaya, A., Unlu, I., Akar, M. S., \& Sagirli, M. O. (2011). The effects of motion pictures about school and teachers on the professional attitudes and self-efficacy perceptions of prospective teachers. Journal of Educational Sciences in Theory and Practice, 11(4), 1765-1783.

Karakucuk, Suna A. (2011). Teacher in Turkish and world Cinema. Journal of Science and Future, 95, 65-73.

Kaya, E., \& Cengelci, T. (2011). Opinions of prospective teachers on utilizing movies in social sciences education. Journal of Research on Social Sciences Education, 2(1), 116-135.

Kocak, S. (2007). Dead Poets Society 1\&2. Retrieved from http://blog.milliyet.com.tr/kocaks

Kus, E. (2003). Quantitative-qualitative research techniques. Ankara: An1 Publication.

Lawson, T. J., Bodle, J. H., \& McDonough, T. A. (2007). Techniques for increasing student learning from educational videos: notes versus guiding questions. Teaching of Psychology, 34(2), 90-93.

Metz, C. (2012). Film language: A semiotics of the cinema. (Trans. O. Adanır). Izmir: Hayalperest Publication House.

Michel, E., Roebers, C. M., \& Schneider, W. (2007). Educational films in the classroom: increasing the benefit. Learning and Instruction, 17(2), 172-183.

Mitry, J. (1989). The aesthetics and psychology of the cinema. (Trans. O. Adanır). Izmir: Dokuz Eylul Publications.

Monaco, J. (2001). How to read a film? (Trans. E. Yilmaz). Istanbul: Oglak Publication House.

Moreno, R. A. Mayer, R. E. (1999). Cognitive principles of multimedia learning: The role of modality and contiguity. Journal of Educational Psychology, 91(2), 358-368.

Ozon, N. (1964). Guidebook to cinema. Istanbul: Elif Publications.

Oztas, S. (2008). History education and movies. Kastamonu Journal of Education, 16(2), 543-556.

Oztas, S. (2009). Use of films in social science education. M. Safran (Ed.), Social Sciences 
Education (pp. 341-360). Ankara: Pegem Academy.

Pekdag, B., \& Le Marechal, J.F. (2007). Preparation of scientific movies. Necatibey Faculty of Education Journal of Science and Mathematics Education, 1(1), 57-84.

Rabow, M. W., Goodman, S., Chang, S., Berger, M., \& Folkman, S. (2010). Filming the family: a documentary film to educate clinicians about family caregivers of patients with brain tumors. Journal of Cancer Education, 25, 242-246.

Sevim, B. (2011). Adolescence: Thin line between seizing the day and depression. [Online] Available: Ajanspsikoloji.com/436 (June 1, 2013).

Tezcan, M. (1972). Cinema in our social life and its role in public education. Ankara University Journal of Education Sciences, 5(3), 171-204.

Yesilyurt, A. (2010). Learning and change (A study of self-assessment). NEU Journal of Social Science, 3(1), 2-17.

Whiteman, D. (2009). Documentary film as policy analysis: The impact of yes, in my backyard on activists, agendas and policy. Mass Communication and Society, 12(4), 457-477. http://www. filmeducation.org.

\section{Copyright Disclaimer}

Copyright reserved by the author(s).

This article is an open-access article distributed under the terms and conditions of the Creative Commons Attribution license (http://creativecommons.org/licenses/by/3.0/). 